\title{
An Improved Cambridge Filter Pad Extraction Methodology to Obtain More Accurate Water and "Tar" Values: In Situ Cambridge Filter Pad Extraction Methodology*
}

\author{
by \\ David Ghosh and Cyril Jeannet
}

Philip Morris International, Research and Development, Quai Jeanrenaud 5, 2000 Neuchâtel, Switzerland.

\section{SUMMARY}

Previous investigations by others and internal investigations at Philip Morris International (PMI) have shown that the standard trapping and extraction procedure used for conventional cigarettes, defined in the International Standard ISO 4387 (Cigarettes -- Determination of total and nicotine-free dry particulate matter using a routine analytical smoking machine), is not suitable for high-water content aerosols. Errors occur because of water losses during the opening of the Cambridge filter pad holder to remove the filter pad as well as during the manual handling of the filter pad, and because the commercially available filter pad holder, which is constructed out of plastic, may adsorb water. This results in inaccurate values for the water content, and erroneous and overestimated values for Nicotine Free Dry Particulate Matter (NFDPM). A modified $44 \mathrm{~mm}$ Cambridge filter pad holder and extraction equipment which supports in situ extraction methodology has been developed and tested. The principle of the in situ extraction methodology is to avoid any of the above mentioned water losses by extracting the loaded filter pad while kept in the Cambridge filter pad holder which is hermetically sealed by two caps. This is achieved by flushing the extraction solvent numerous times through the hermetically sealed Cambridge filter pad holder by means of an in situ extractor. The in situ methodology showed a significantly more complete water recovery, resulting in more accurate NFDPM values for high-water content aerosols compared to the standard ISO methodology. The work presented in this publication demonstrates that the in situ extraction methodology applies to a wider range of smoking products and smoking regimens, whereas the standard ISO methodology only applies to a limited range of smoking products and smoking regimens, e.g., conventional cigarettes smoked under ISO smoking regimen. In cases where a comparison of yields between the PMI HTP and conventional cigarettes is required the in situ extraction methodology must be used for the aerosol of the PMI HTP to obtain accurate NFDPM/"tar" values. This would be for example the case if there were a need to print "tar" yields on packs or compare yields to ceilings. Failure to use the in situ extraction methodology will result in erroneous and overestimated NFDPM/"tar" values. [Beitr. Tabakforsch. Int. 26 (2014) 38-49]

\section{ZUSAMMENFASSUNG}

Frühere Untersuchungen anderer Gruppen und interne Untersuchungen von Philip Morris International (PMI) haben gezeigt, dass die Standard-Auffang- und Extraktionsmethode für konventionelle Zigaretten nach ISO 4387 (Cigarettes -- Determination of total and nicotine-free dry particulate matter using a routine analytical smoking machine) nicht für Aerosole mit hohem Wassergehalt geeignet ist. Fehler entstehen aufgrund von Wasserverlusten durch das Öffnen des Cambridge Filterhalters zur Entnahme des Filters, während der Handhabung des Filters sowie aufgrund von Wasser-Adsorption durch das Filtergehäuse aus Plastik. Dies führt zur ungenauen Wassergehaltbestimmung und dadurch zu fehlerhaften und überbe- 
werteten Werten bei nikotinfreiem Trockenkondensat (NFDPM). Es wurde ein modifizierter $44 \mathrm{~mm}$ Cambridge Filterhalter mit Extraktionsgerät zur in situ Extraktion entwickelt und getestet. Das Prinzip dieser in situ Extraktionsmethode ist, die oben erwähnten Wasserverluste zu vermeiden, indem der beladene Filter im Cambridge Filterhalter, welcher durch zwei Stopfen hermetisch verschlossen ist, extrahiert wird. Dies wird erreicht, indem die Extraktionslösung mit Hilfe eines in situ Extraktors mehrfach durch den hermetisch verschlossenen Cambridge Filterhalter gespült wird. Die in situ Extraktionsmethode zeigte eine signifikant vollständigere Wasserrückgewinnung, was verglichen mit der Standard ISO Methode zu genaueren nikotinfreien Trockenkondensat-Werten für Aerosole mit hohem Wassergehalt führt. Die Arbeit, die in dieser Publikation präsentiert wird, zeigt, dass die in situ Extraktionsmethode auf eine größere Palette an Rauchprodukten und Abrauchnormen anwendbar ist, während die Anwendung der Standard ISO Methode begrenzt ist, beispielsweise auf konventionelle Zigaretten, die unter der ISO Abrauchnorm geraucht werden. In Fällen, wo ein Vergleich von Werten zwischen dem PMI HTP und konventionellen Zigaretten notwendig ist, muss für das Aerosol des PMI HTP die in situ Extraktionsmethode angewendet werden, um genaue NFDPM/“Teer" Werte zu erhalten. Dies wäre zum Beispiel der Fall, wenn „Teer“ Werte auf Packungen gedruckt oder Grenzwerte verglichen werden müßten. Wird die in situ Extraktionsmethode nicht angewendet, führt dies zu fehlerhaften und überbewerteten Werten für NFDPM/“Teer"، [Beitr. Tabakforsch. Int. 26 (2014) 38-49]

\section{RESUME}

De précédentes investigations conduites par d'autres organisations ainsi que des investigations internes à Philip Morris International (PMI) ont montré que la procédure de trappage et d'extraction appliquée aux cigarettes conventionnelles, décrite par la norme internationale ISO 4387 (Cigarettes -- Détermination de la matière particulaire totale et de la matière particulaire anhydre et exempte de nicotine au moyen d'une machine à fumer analytique de routine), n'est pas adaptée pour des aérosols contenant une grande quantité d'eau. Des erreurs sont induites dues aux pertes d'eau lors de l'ouverture du porte-filtre Cambridge pour enlever le filtre et aussi durant la manipulation du filtre ainsi que par l'adsorption d'eau par des porte-filtres en polymère. Cela conduit à des valeurs incorrectes d'eau, et ainsi à des valeurs erronées et surestimées de matière particulaire anhydre et exempte de nicotine (NFDPM). Un système d'extraction du porte-filtre Cambridge $44 \mathrm{~mm}$ basé sur une méthode d'extraction in situ a été développé et testé. Le principe de la méthode d'extraction in situ est d'éliminer les pertes en eau décrites ci-dessus par extraction du filtre chargé en le gardant dans le porte-filtre maintenu fermé de manière hermétique à l'aide de bouchons. Cela est réalisé en passant le solvant d'extraction au travers du filtre plusieurs fois via le porte-filtre maintenu hermétiquement fermé en utilisant un extracteur in situ. La méthode d'extraction in situ a montré un rendement d'extraction plus complet de l'eau conduisant à une valeur plus correcte de goudron pour des aérosols contenant beaucoup d'eau en comparaison à la méthode décrite par la norme ISO. Le travail présenté dans cette publication démontre que la méthode d'extraction in situ s'applique à une gamme plus large de produits à fumer et de régimes de fumage alors que la méthode décrite par la norme ISO ne s'applique qu'à une gamme limitée de produits à fumer et de régimes de fumage, comme par exemple des cigarettes conventionnelles fumées avec un régime de fumage décrit par la norme ISO. Si une comparaison des rendements entre le HTP de PMI et des cigarettes conventionnelles est demandée, la méthodologie d'extraction in situ doit être appliquée à l'aérosol du HTP de PMI afin d'obtenir des valeurs de goudron (NFDPM) correctes. Cela serait le cas, par exemple, s'il était nécessaire d'imprimer les rendements en goudron sur les paquets ou de comparer les rendements à des limites hautes. En n'appliquant pas la méthodologie d'extraction in situ cela conduirait à des valeurs fausses et surestimées de goudron (NFDPM). [Beitr. Tabakforsch. Int. 26 (2014) 38-49]

\section{INTRODUCTION}

Nicotine free dry particulate matter (NFDPM) is the term used in the ISO Standard referring to "tar". Based on standardized smoking machine methods $(1,2)$ many countries require cigarette manufacturers to report to their respective governments and/or print the yields of "tar", nicotine, and $\mathrm{CO}$ (TNCO) per cigarette on the cigarette pack. In Europe, Directive 2001/37/EC also established ceilings - maximum limits - for "tar", nicotine, and carbon monoxide yields per cigarette, based on the ISO smoking protocol $(1,3)$. Relevant internationally recognized standardized methodologies have been developed and updated over many years and are summarized elsewhere (4-6). Smoke is collected under a standard machine smoking regimen developed by the INTERNATIONAL ORGANIZATION FOR STANDARDIZATION (1) and TNCO yields are measured from the collected smoke using prescribed ISO testing methods (7-10). Similar procedures are followed by HEALTH CANADA Intense (2). Regardless of which standardized methodology is applied, in order to guarantee an accurate "tar" value a complete water recovery without any losses is essential. This is increasingly challenging for aerosols containing elevated water quantities. The corollary is that water losses directly lead to erroneous and overestimated "tar" values.

Previously, CôTÉ et al. $(11,12)$ have investigated whether the standard trapping and extraction procedure for total particulate matter (TPM), water, nicotine and "tar" under ISO Standard 4387 is appropriate for more intense smoking regimens, as the smoke of more intense smoking regimens produces higher TPM yields containing a higher water content. Their work focuses on sources of errors inherent in the method, i.e., the delay between the weighing and extraction process and losses during the manual removal of the filter pad followed by an incomplete wiping of the filter pad holder walls. CôTÉ et al. were able to demonstrate that the standard trapping and extraction procedure defined in the International Standard ISO 4387 (7) results in a "tar" overestimation of about $20 \%-25 \%$ for lit-end conventional cigarettes (CC) smoked under Health Canada Intense (HCI) 
smoking regimen. CôTÉ et al. also demonstrated that water and volatile components are released from the Cambridge filter pad holder upon its opening and that a residual mass is left in the Cambridge filter pad holder after extraction which is not further analyzed. CôTÉ et al. proposed two alternative methodologies to the standard trapping and extraction procedure defined in the International Standard ISO 4387 (7): the "in-flask weighing method" and the "closed-circuit extraction method". The methodology of the latter method is similar to the in situ extraction methodology which we developed and present in this publication and is based on a complete filter pad extraction without opening or wiping of the filter pad holder. The "closed-circuit extraction" is achieved by flushing $20 \mathrm{~mL}$ of extraction solvent during $90 \mathrm{~min}$ at a flow rate of $25 \mathrm{~mL} / \mathrm{min}$ through the Cambridge filter pad holder containing the Cambridge filter pad by means of a peristaltic pump. It was demonstrated that the method resulted in a more complete extraction by avoiding water losses because the Cambridge filter pad holder was not opened and consequently neither was the interior of the Cambridge filter pad holder wiped. The "closed-circuit extraction method" resulted in significant differences for the "tar" value obtained from a $14 \mathrm{mg}$ ISO "tar" CC smoked under Health Canada Intense smoking regimen compared to when applying the standard trapping and extraction procedure defined in the International Standard ISO 4387 (7).

Tobacco products that are heated and not combusted produce an aerosol that has a less complex chemical composition and contains reduced levels of harmful and potentially harmful components as well as a lot more water than CC smoke. BORGERDING et al. claim that on the basis of the chemistry of their heated tobacco product, it is inappropriate to calculate a classical "tar" value (13). BORGERDING et al. therefore use the term "Flavor/Other" instead of "tar" which is mathematically equivalent to 'Humectant Free Nicotine Free Dry Particulate Matter' (TPM - (glycerin + propylene glycol) - nicotine - water). Further, BORGERDING et al. (14) have published the limitations of standard Cambridge filter collection for further nicotine, glycerin, propylene glycol, and water determination of heated tobacco aerosols. BORGERDING et al.were able to demonstrate that the standard trapping and extraction procedure defined in the International Standard ISO 4387 (7) is not appropriate for heated tobacco products and results in a 'Humectant Free Nicotine Free Dry Particulate Matter' overestimation of about 25\%. The authors have observed that Cambridge filters coated with aerosols from heated tobacco products have a much greater propensity for evaporative water loss compared to Cambridge filters coated with smoke from CCs, leading to the above mentioned inflated 'Humectant Free Nicotine Free Dry Particulate Matter' values. They attributed the evaporative water losses to a combination of effects from both: the elevated water content of the aerosol of heated tobacco products relative to smoke of CCs and the unique aerosol matrix of heated tobacco products. BORGERDING et al. developed and tested a methodology which is similar to the in situ extraction methodology which we developed and present in this publication as it is based on a complete extraction without opening or wiping of the filter pad holder. The Cambridge filter pad was extracted while still kept remaining in the Cambridge filter pad holder by adding the solvent directly to the sealed filter pad holder containing the filter pad and extracting the closed system for $30 \mathrm{~min}$ by continuous agitation. The obtained values using the in-holder filter extraction for TPM, nicotine, glycerin, and propylene glycol yields were equivalent to those from the standard trapping and extraction procedure experiments. Water values, however, increase significantly and, correspondingly, the 'Humectant Free Nicotine Free Dry Particulate Matter' values decrease.

Also our investigations have shown that the standard trapping and extraction procedure used for CCs, defined in the International Standard ISO 4387 (7), is not suitable for the high-water content present in heated tobacco aerosols. Errors occur because of water losses during the opening of the Cambridge filter pad holder to remove the filter as well as during the manual handling of the filter, which is comprised by the removal of the filter by forceps, further folding of the filter, careful holding of the filter by forceps or by gloved hands, and also due to incomplete wiping of the filter pad holder walls after removal of the pad. Further, the commercially available filter pad holder, which is constructed out of plastic, may adsorb water. This results in inaccurate values for the water content, and erroneous and overestimated values for Nicotine Free Dry Particulate Matter (NFDPM). In this publication we present a modified $44 \mathrm{~mm}$ Cambridge filter pad holder and extraction equipment which supports in situ extraction methodology. Our investigation has shown that applying this methodology results in a more complete water recovery for aerosols with high-water content.

\section{THE IN SITU EQUIPMENT AND METHODOLOGY}

An in situ filter pad extraction equipment and methodology was developed with the objective to ensure complete water recovery and avoid the above mentioned losses. Briefly, the methodology functions as follows: The Cambridge filter pad holder containing the filter pad and the washer is hermetically sealed after smoking. The extraction solvent is flushed numerous times through the hermetically sealed Cambridge filter pad holder containing the Cambridge filter pad, without allowing any humidity to enter or exit the Cambridge filter pad holder. By flushing the extraction solvent numerous times through the Cambridge filter pad holder a complete extraction of all trapped material on the Cambridge filter pad, the washer and on the holder walls is achieved. The extract is further chemically analyzed. By following this approach water losses are avoided during the opening of the Cambridge filter pad holder to remove the filter pad as well as during the manual handling of the filter pad which is comprised by the removal of the filter by forceps, further folding of the filter, careful holding of the filter by forceps or by gloved hands, and also due to incomplete wiping of the filter pad holder walls after removal of the pad.

The in situ equipment consists of a $44 \mathrm{~mm}$ diameter metallic pad holder fabricated out of aluminum alloy which is covered by a $10 \mu \mathrm{m}$ nickel layer. The mouth piece is from Cerulean and contains four labyrinth seals. The washer is located at the inlet of the pad holder and can, 

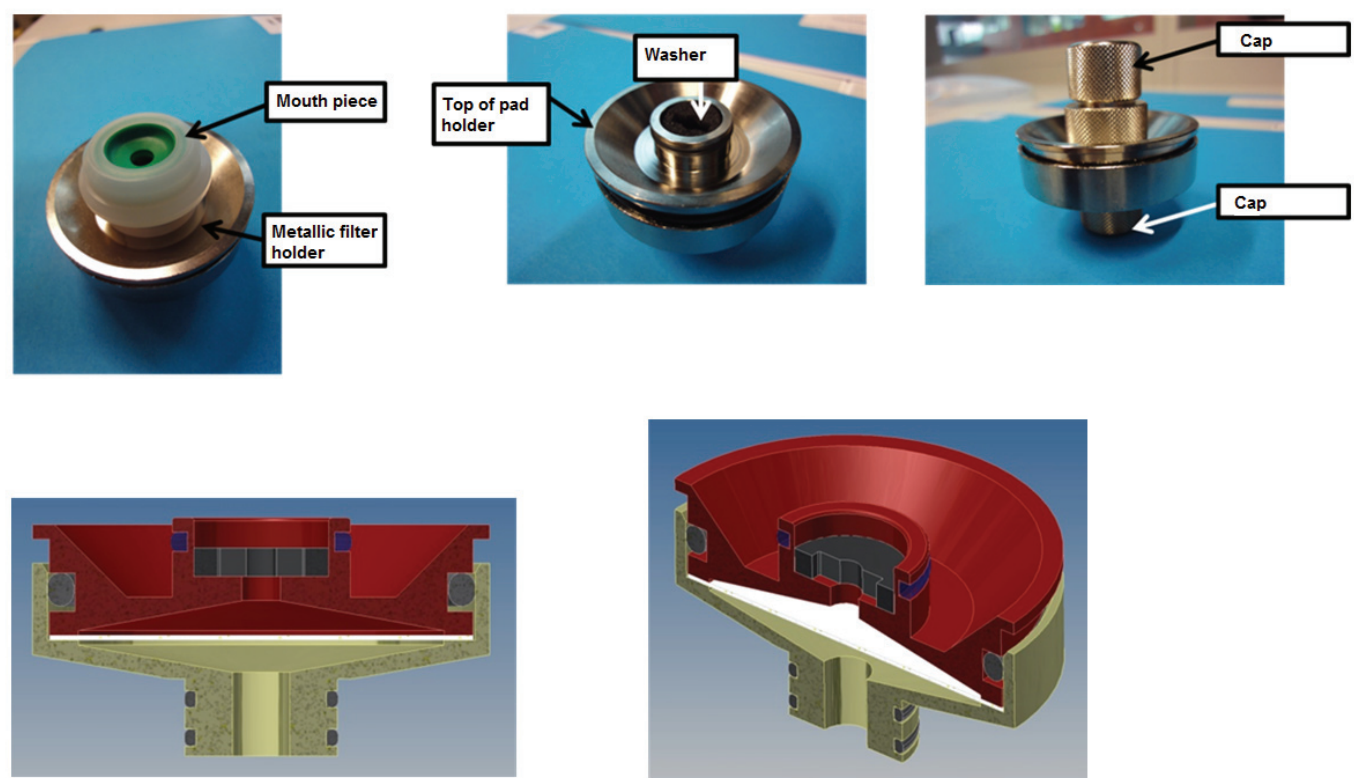

Figure 1. In situ Cambridge filter pad holder.

thus, be included in the in situ extraction process to ensure a complete extraction of all trapped matter. The in situ extraction methodology per se does not include the mouth piece in the weighing process since the mouth piece needs to be removed in order to hermetically seal the pad holder. We therefore chose this mouth piece as it allows an extraction of the complete trap, the $44 \mathrm{~mm}$ Cambridge filter including the washer, while following as close as possible to the ISO norm 4387 which states that the mouth piece must not be included in the weighing process if the washer is located on the inlet of the pad holder. Figure 1 shows the in situ Cambridge filter pad holder.

The experimental procedure functions as follows (see Figure 2). Before smoking, the in situ Cambridge filter pad holder containing a Cambridge filter pad and a washer is hermetically sealed by two caps each containing a septum and weighed. For the smoking, the caps are removed and a mouth piece is attached to the in situ Cambridge filter pad holder. Directly after smoking, the mouth piece is removed and the two caps are used to hermetically seal the in situ Cambridge filter pad holder containing the loaded Cambridge filter pad and the washer. The hermetically sealed in situ Cambridge filter pad holder is weighed again. Following the International Standard ISO 4387 (7) the mouth piece weight is not included in the weighing process as the washer is located at the inlet of the pad holder. Total Particulate Matter (TPM) is calculated by subtracting the measured weight obtained before and after smoking.

After smoking and weighing the Cambridge filter pad and the washer are kept in the hermetically sealed Cambridge filter pad holder in order to be in situ extracted. To do so the hermetically sealed Cambridge filter pad holder is introduced into the in situ extractor (Figure 3). One syringe filled with $10 \mathrm{~mL}$ isopropanol and one empty syringe are pierced through the septum contained in the caps and connected to the in situ extractor (Figure 3 left). By alternating up and down movements of the syringe pistons the solvent is flushed approx. 60 times during $30 \mathrm{~min}$ through the Cambridge filter pad holder.

To minimize the amount of solvent used in order to reduce costs and the environmental footprint, we use $10 \mathrm{~mL}$ of isopropanol, opposed to $20 \mathrm{~mL}$ which was used by CôTÉ et al. (12) and which is recommended by the standard trapping and extraction procedure defined in the International Standard ISO 4387 (7) and by the CORESTA Recommended Method No 23 (15), as we have found that this volume is sufficient and just as effective for the extraction process.

At the end of the extraction process the solvent extract is collected in a vial for subsequent chemical analysis.

\section{ANALYTICAL METHODS}

Smoking was performed on Borgwaldt KC Inc. linear machines type LM20x (Northern Chesterfield, VA, USA). Following the aerosol collection as described above the extract was then chemically analyzed via the following methods:

TPM was gravimetrically determined from $44 \mathrm{~mm}$ glass fiber filter pads by measuring the weight of the filter pad placed in the filter pad holder before and after smoking. $\mathrm{CO}$ was determined without further treatment of the aerosol with a CO meter located at the outlet of the filter pad holder by non-dispersive infrared absorption gas analyzers from the company Borgwaldt $\mathrm{KC}$ Inc., type $\mathrm{CO} / \mathrm{CO} 2$-Analyzer C25, (Northern Chesterfield, VA, USA) and by Fourier transformed infrared analyzers from the company California Analytical Instruments Inc., type CAL Series 600 FTIR, (Orange, CA, USA).

Nicotine yields were determined by analyzing the extract with a Thermo Scientific Trace gas chromatograph Trace GC Ultra equipped with a flame ionization detector (Thermo Electron S.p.A., Rodano, Italy). A 7\% Carbowax 20M $3 \%$ polyphenylether OS 138 and $2 \% \mathrm{KOH}$ column with a length of 4 feet and an external diameter of $1 / 8$ inch was 


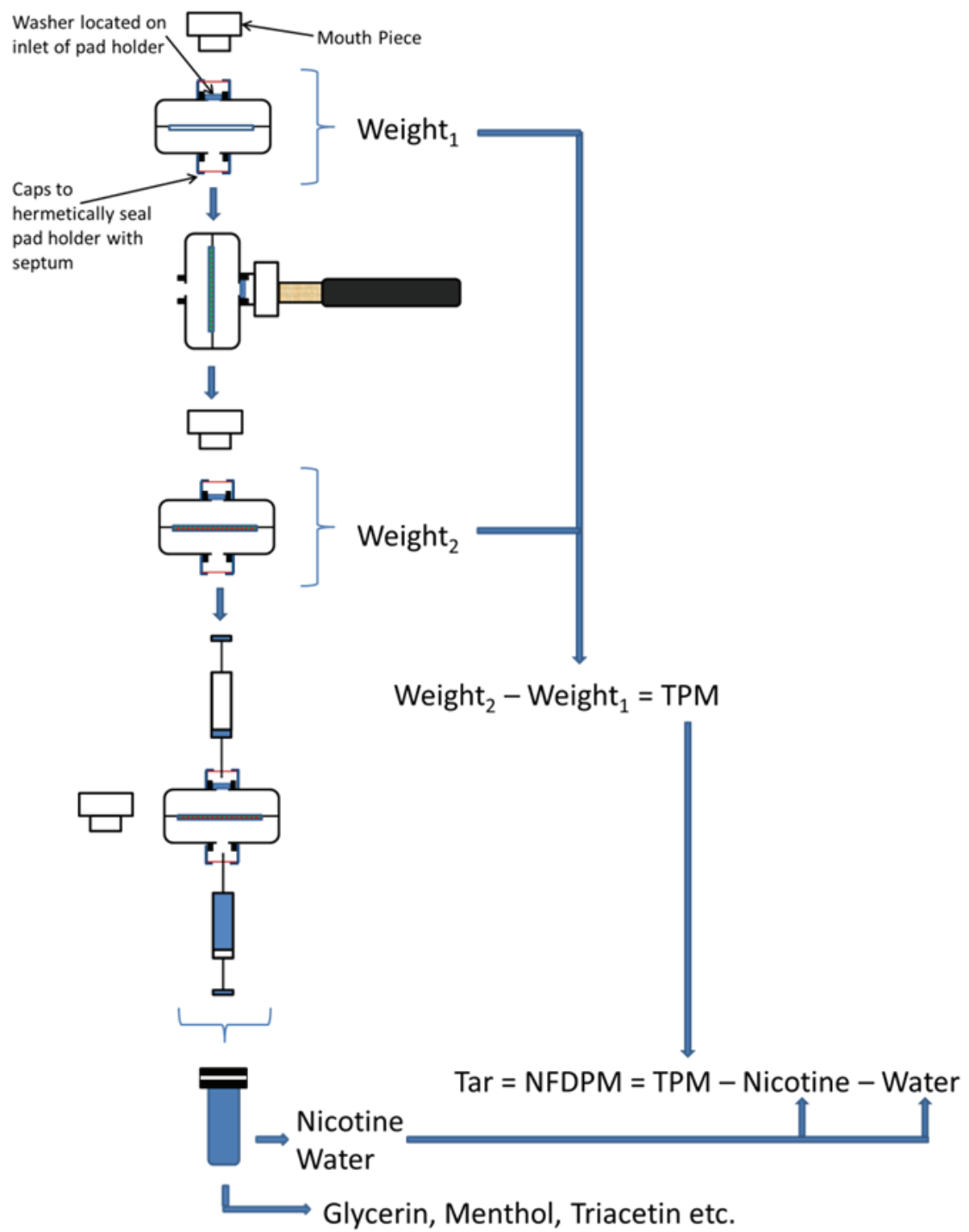

Figure 2. Schematic of in situ experimental procedure.

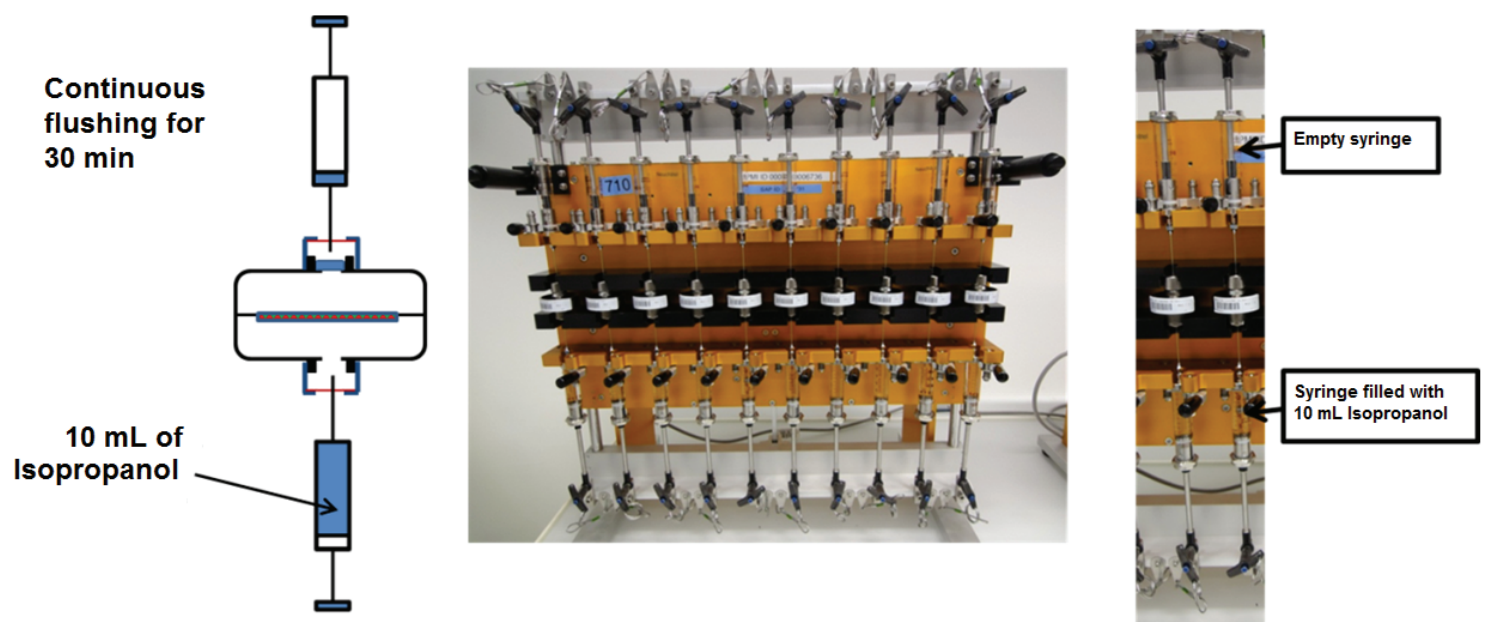

Figure 3. The in situ extractor. 
used. The oven temperature was set at $170{ }^{\circ} \mathrm{C}$ for $5 \mathrm{~min}$ and the detector temperature was set at $250{ }^{\circ} \mathrm{C}$. As carrier gas Helium with a constant flow of $45 \mathrm{~mL} / \mathrm{min}$ was used. A volume of $1 \mu \mathrm{L}$ was injected in splitless mode at $200{ }^{\circ} \mathrm{C}$.

Water yields were determined by analyzing the extract with a Thermo Scientific Trace gas chromatograph equipped with a thermal conductivity detector. A Haysep Q 80/100 mesh column with a length of 8 feet and an external diameter of 1/8 inch was used (BGB Analytik AG, Geneva, Switzerland). The oven temperature was set at $170^{\circ} \mathrm{C}$ for $5 \mathrm{~min}$ and the detector temperature was set at $250{ }^{\circ} \mathrm{C}$. As carrier gas Helium with a constant flow of $45 \mathrm{~mL} / \mathrm{min}$ was used. A volume of $2 \mu \mathrm{L}$ was injected in splitless mode at $200{ }^{\circ} \mathrm{C}$.

Glycerin yields were determined by analyzing the extracts with a PerkinElmer Clarus 500 gas chromatograph equipped with a flame ionization detector (Waltham, MA, USA). A DB-Wax column with a length of $30 \mathrm{~m} \times 0.53 \mathrm{~mm}$ ID $\times 0.10 \mathrm{~mm}$ film thickness was used. The oven temperature was set at $100^{\circ} \mathrm{C}$ for 2 min followed by a heating rate of $10^{\circ} \mathrm{C} / \mathrm{min}$ up to $150^{\circ} \mathrm{C}$. Following this the oven temperature was stabilized for $1 \mathrm{~min}$ at $150^{\circ} \mathrm{C}$ and then a second heating rate of $20{ }^{\circ} \mathrm{C} / \mathrm{min}$ up to $200{ }^{\circ} \mathrm{C}$ was applied. The temperature was then again stabilized at $200^{\circ} \mathrm{C}$ for $3 \mathrm{~min}$. The detector temperature was set at $250^{\circ} \mathrm{C}$. As carrier gas Helium with a constant flow of $12 \mathrm{~mL} / \mathrm{min}$ was used. A volume of $1 \mu \mathrm{L}$ was injected in split mode with a split ratio of 10 at $200{ }^{\circ} \mathrm{C}$.

NFDPM is a calculated value which is obtained by subtracting the nicotine and water yield from the TPM.

$$
\mathrm{NFDPM}=T P M-\text { nicotine }- \text { water }
$$

\section{TEST ITEMS}

As test items the $3 \mathrm{R} 4 \mathrm{~F}$ Reference cigarette from the University of Kentucky, a $6 \mathrm{mg}$ "tar", $0.5 \mathrm{mg}$ nicotine and $7 \mathrm{mg}$ CO PMI conventional cigarette (CC) and a PMI Heated Tobacco Product (HTP) were used. The PMI HTP consists of a heating device which precisely controls the heating mechanism into which a specially designed tobacco stick is inserted to generate an aerosol at operating temperatures that are significantly below the level of combustion. The tobacco stick comprises a processed tobacco plug that contains glycerin as an aerosol former. The tobacco plug is heated via the heating device and not burned. The resulting aerosol compositions is less complex and contains more water than $\mathrm{CC}$ smoke. Figure 4 shows a photo of the current generation of PMI Heated Tobacco Product which was used.

\section{DESIGN OF EXPERIMENT AND STATISTICAL METHOD}

The in situ extraction methodology was compared vs. the standard ISO methodology by smoking the 3R4F Reference cigarette, a PMI CC and a PMI HTP under ISO and HCI smoking regimen. For each smoking regimen and test item the respective yields for TPM, nicotine, glycerin, water, NFDPM and CO obtained by the in situ extraction

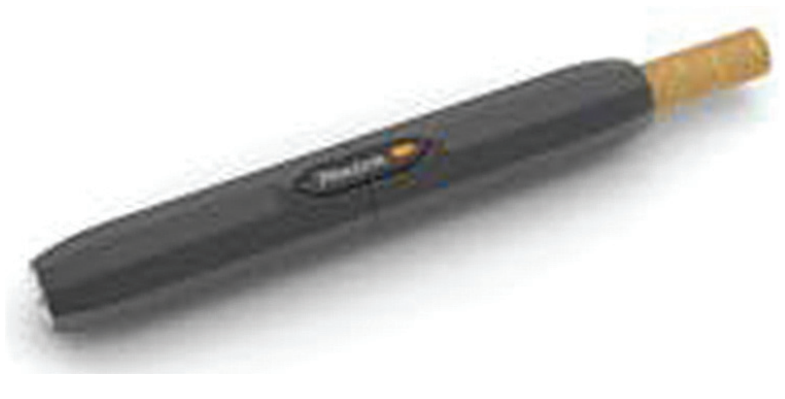

Figure 4. Photo of a current generation of PMI Heated Tobacco Product.

methodology were statistically compared to those obtained by the standard ISO methodology. The statistical analysis was performed to calculate the accuracy and the precision according to the UNITED STATES PHARMACOPEIA (USP) General chapter $<1010>$ Comparison of Analytical Methods (16).

A sample size of 15 was chosen for each smoking regimen and test item. For this, five replicates were smoked per day and test item on three separate days (Table 1). The statistical techniques used to assess the accuracy and the precision were based on confidence intervals in order to increase the power and the resulting robustness of the conclusions.

Table 1. Summary of experiments. 15 samples $=3$ days $\times 5$ replicates.

\begin{tabular}{l|c|c|c|c}
\hline & \multicolumn{2}{|c|}{ ISO smoking regimen } & \multicolumn{2}{c}{$\mathrm{HCl}$ smoking regimen } \\
\cline { 2 - 5 } & $\begin{array}{c}\text { Standard ISO } \\
\text { (samples) }\end{array}$ & $\begin{array}{c}\text { In situ } \\
\text { (samples) }\end{array}$ & $\begin{array}{c}\text { Standard ISO } \\
\text { (samples) }\end{array}$ & $\begin{array}{c}\text { In situ } \\
\text { (samples) }\end{array}$ \\
\hline $\begin{array}{l}\text { 3R4F } \\
\begin{array}{l}\text { Reference } \\
\text { cigarette }\end{array}\end{array}$ & $15^{\mathrm{a}}$ & $15^{\mathrm{a}}$ & $15^{\mathrm{b}}$ & $15^{\mathrm{b}}$ \\
PMI CC & $15^{\mathrm{a}}$ & $15^{\mathrm{a}}$ & $15^{\mathrm{b}}$ & $15^{\mathrm{b}}$ \\
PMI HTP & $15^{\mathrm{a}}$ & $15^{\mathrm{a}}$ & $15^{\mathrm{c}}$ & $15^{\mathrm{c}}$ \\
\hline
\end{tabular}

a 5 tobacco sticks/cigarettes collected per replicate

b 2 cigarettes collected per replicate

c 2 tobacco sticks collected per replicate

All individual results were assessed for the presence of possible outliers using the modified Z-score based on the median absolute deviation. All identified outlying values which were traced back to an analytical error, e.g., contamination in the laboratory or malfunctions during smoke or aerosol generation, were disregarded from the data set and subsequent statistical analysis.

To assess whether the difference for a given analyte between the in situ extraction methodology and the standard ISO methodology is significant the confidence interval for the difference between the two methodologies was calculated. If the confidence interval for the difference between the in situ extraction methodology and the standard ISO methodology does not include the zero, significant differences between the methods in terms of accuracy are found while if the confidence interval includes the zero then no significant differences in the accuracy of the two methodologies can be assessed. 
Lower limit $=$

$\left(M_{2}-M_{1}\right)-t_{1-\alpha / 2,(n 1-1)+(n 2-1)} \times \sqrt{\frac{\left(S_{1}^{2}+S_{2}^{2}\right)}{n}}$

$$
\begin{aligned}
& \text { Upper limit }= \\
& \left(M_{2}-M_{1}\right)+t_{1-\alpha / 2,(n 1-1)+(n 2-1)} \times \sqrt{\frac{\left(S_{1}^{2}+S_{2}^{2}\right)}{n}}
\end{aligned}
$$

In equation 2 and $3 \mathrm{n}$ is the number of results, $\mathrm{t}$ is the student distribution with $\alpha$ (type I error) set to $0.05, \mathrm{M}$ is the estimated average, and $\mathrm{S}^{2}$ is the variance. The subscript 1 refers to the in situ extraction methodology and the subscript 2 refers to the standard ISO methodology.

The precision was assessed for the in situ extraction methodology compared to that of the standard ISO methodology by estimating the variance for both methodologies and calculating a one-sided upper confidence interval for the ratio of the variances. The ratio is defined as the variance of the in situ extraction methodology to that of the standard ISO methodology [equation 4]. If the one-sided upper confidence interval is less than the upper acceptable limit, then the precision of the new method is considered acceptable in the sense that the use of the new method will not lead to an important loss in precision. The upper acceptable limit is set to be 1 [equation 4].

$$
1>\frac{\mathrm{S}_{1}^{2}}{\mathrm{~S}_{2}^{2}} \frac{1}{\mathrm{~F}_{\alpha, \mathrm{n} 1-1, \mathrm{n} 2-1}}
$$

In equation $4 \mathrm{~S}_{1}^{2}$ is the variance of the in situ extraction methodology and $\mathrm{S}_{2}^{2}$ is the variance of the standard ISO methodology. F is Fisher's distribution with $\alpha$ (type I error) set to $0.05, \mathrm{n} 1$ is the number of results for the in situ extraction methodology and $\mathrm{n} 2$ the number of results for the standard ISO methodology.

Even though CO is not directly linked to the determination of NFDPM, we have included the results for $\mathrm{CO}$ in this publication as $\mathrm{CO}$ was and is normally measured together with the other analytes in one set of experiments. It is, therefore, useful to demonstrate that the $\mathrm{CO}$ values are not affected by the Cambridge pad holder in any manner, especially, because some countries require cigarette manufacturers to report to their respective governments and/or print $\mathrm{CO}$ per cigarette in addition to the yields of "tar" and nicotine per cigarette on the cigarette pack.

\section{RESULTS}

The water yields using the in situ extraction methodology for a PMI HTP were found to be $24 \%$ and $19 \%$ higher compared to those obtained using the standard ISO methodology under ISO and under HCI smoking regimen, respectively. The difference in absolute water yields between both methodologies is larger for the HCI smoking regimen $(7.1 \mathrm{mg} / \mathrm{cig})$ compared to the ISO smoking regimen (4.5 mg/cig). The resulting NFDPM values for both smoking regimens are reduced by a factor of two when using the in situ extraction methodology compared to the standard ISO methodology (Tables 2, 3 and 4). Figure 5 summarizes the results graphically. Under ISO and HCI smoking regimen there are no significant differences for TPM, glycerin, nicotine and CO between the yields obtained with the in situ extraction methodology compared to the standard ISO methodology (Table 5).

The water yields using the in situ extraction methodology for the 3R4F Reference cigarette were found to be $70 \%$ and $54 \%$ higher compared to those obtained using the standard ISO methodology under ISO and under HCI smoking regimen, respectively. The difference in absolute water deliveries between both methodologies is much larger for the HCI smoking regimen $(7.2 \mathrm{mg} / \mathrm{cig})$ compared to the ISO smoking regimen $(0.5 \mathrm{mg} / \mathrm{cig})$. The resulting NFDPM value using the in situ extraction methodology is reduced by $23 \%$ under HCI smoking regimen compared to the standard ISO methodology. The $4 \%$ reduction of the NFDPM value under ISO smoking regimen is statistically significant, however, not relevant according to the reporting requirements set forth in the ISO Standard 8243 (17) for printing of "tar", nicotine and CO yields per cigarette on cigarette packs (Tables 2, 3 and 4). Figure 6 summarizes the results graphically. Under ISO smoking regimen there are no statistical significant differences for TPM, glycerin, nicotine and $\mathrm{CO}$ between the values obtained with the in situ extraction methodology compared to the standard ISO methodology (Table 5). Under HCI smoking regimen the in situ extraction methodology resulted in 9\% higher glycerin and 5\% higher nicotine yields compared to the standard ISO methodology while no significant differences were found between both methodologies for TPM and CO (Table 5).

The water yields using the in situ extraction methodology for the PMI CC were found to be $35 \%$ and $26 \%$ higher compared to those obtained using the standard ISO methodology under ISO and under HCI smoking regimen, respectively. The difference in absolute water deliveries between both methodologies is much larger for the HCI smoking regimen (3.2 $\mathrm{mg} / \mathrm{cig})$ compared to the ISO smoking regimen $(0.2 \mathrm{mg} / \mathrm{cig})$ (Tables 2,3 and 4$)$. The resulting NFDPM values using the in situ extraction methodology are reduced for the HCI smoking regimen by $17 \%$ compared to the standard ISO methodology, while no significant differences were found for the ISO smoking regimen. Figure 7 summarizes the results graphically. Under ISO and HCI smoking regimen no significant differences were found for TPM, glycerin, nicotine and $\mathrm{CO}$ between the yields obtained with the in situ extraction methodology compared to the standard ISO methodology (Table 5).

\section{DISCUSSION}

For all investigated cases (CCs and a PMI HTP; ISO and HCI smoking regimen) a significantly more complete water recovery was obtained using the in situ extraction methodology while only an incomplete water recovery was obtained using the standard ISO methodology. The incomplete water recovery observed for the standard ISO methodology results in higher NFDPM values because the NFDPM is only partially dry. This effect is more pronounced for high-water content aerosols such as the aerosol 
Table 2. Summary of results under ISO smoking regimen.

\begin{tabular}{|c|c|c|c|c|c|c|c|}
\hline \multirow{2}{*}{ Analyte } & & \multicolumn{3}{|c|}{ Standard ISO } & \multicolumn{3}{|c|}{ In situ } \\
\hline & & 3R4F CC & PMI CC & PMI HTP & 3R4F CC & PMI CC & PMI HTP \\
\hline \multirow{4}{*}{ TPM } & $\mathrm{N}$ & 15 & 15 & 15 & 15 & 15 & 15 \\
\hline & Average (mg/cig.) & 10.46 & 8.94 & 28.64 & 10.57 & 9.06 & 28.44 \\
\hline & Standard deviation (mg/cig.) & 0.43 & 0.63 & 1.08 & 0.41 & 0.32 & 1.59 \\
\hline & CV $(\%)$ & 4.1 & 7.1 & 3.8 & 3.8 & 3.5 & 5.6 \\
\hline \multirow{4}{*}{ Glycerin } & $\mathrm{N}$ & 15 & 15 & 15 & 15 & 14 & 15 \\
\hline & Average (mg/cig.) & 0.82 & 0.46 & 1.94 & 0.84 & 0.46 & 1.97 \\
\hline & Standard deviation (mg/cig.) & 0.04 & 0.02 & 0.13 & 0.04 & 0.03 & 0.23 \\
\hline & $\mathrm{CV}(\%)$ & 4.3 & 5.2 & 6.8 & 4.7 & 5.8 & 11.7 \\
\hline \multirow{4}{*}{ Nicotine } & $\mathrm{N}$ & 15 & 15 & 15 & 15 & 14 & 15 \\
\hline & Average (mg/cig.) & 0.78 & 0.64 & 0.47 & 0.80 & 0.66 & 0.49 \\
\hline & Standard deviation (mg/cig.) & 0.04 & 0.03 & 0.03 & 0.03 & 0.02 & 0.05 \\
\hline & CV $(\%)$ & 4.6 & 4.6 & 6.0 & 4.0 & 3.4 & 9.6 \\
\hline \multirow{4}{*}{ Water } & $\mathrm{N}$ & 15 & 15 & 15 & 14 & 13 & 15 \\
\hline & Average (mg/cig.) & 0.67 & 0.65 & 18.78 & 1.14 & 0.88 & 23.23 \\
\hline & Standard deviation (mg/cig.) & 0.10 & 0.11 & 1.02 & 0.16 & 0.19 & 1.46 \\
\hline & $\mathrm{CV}(\%)$ & 14.5 & 17.6 & 5.4 & 13.5 & 21.3 & 6.3 \\
\hline \multirow{4}{*}{ NFDPM } & $\mathrm{N}$ & 15 & 15 & 15 & 14 & 13 & 15 \\
\hline & Average (mg/cig.) & 9.01 & 7.65 & 9.39 & 8.64 & 7.54 & 4.71 \\
\hline & Standard deviation (mg/cig.) & 0.44 & 0.54 & 1.24 & 0.30 & 0.37 & 0.59 \\
\hline & $\mathrm{CV}(\%)$ & 4.9 & 7.1 & 13.2 & 3.5 & 4.9 & 12.5 \\
\hline \multirow{4}{*}{$\mathrm{CO}$} & $\mathrm{N}$ & 15 & 15 & 15 & 15 & 15 & 15 \\
\hline & Average (mg/cig.) & 11.67 & 8.38 & 0.30 & 11.46 & 8.25 & 0.32 \\
\hline & Standard deviation (mg/cig.) & 0.56 & 0.50 & 0.03 & 0.43 & 0.46 & 0.05 \\
\hline & CV $(\%)$ & 4.8 & 5.9 & 11.1 & 3.7 & 5.6 & 15.0 \\
\hline
\end{tabular}

Table 3. Summary of results under $\mathrm{HCl}$ smoking regimen.

\begin{tabular}{|c|c|c|c|c|c|c|c|}
\hline \multirow{2}{*}{ Analyte } & & \multicolumn{3}{|c|}{ Standard ISO } & \multicolumn{3}{|c|}{ In situ } \\
\hline & & 3R4F CC & $\mathrm{PMI} C \mathrm{C}$ & PMI HTP & 3R4F CC & PMI CC & PMI HTP \\
\hline \multirow{4}{*}{ TPM } & $\mathrm{N}$ & 15 & 15 & 15 & 15 & 15 & 15 \\
\hline & Average (mg/cig.) & 45.63 & 39.67 & 56.75 & 45.85 & 38.34 & 56.18 \\
\hline & Standard deviation (mg/cig.) & 3.10 & 3.05 & 2.90 & 2.12 & 2.73 & 1.52 \\
\hline & $\mathrm{CV}(\%)$ & 6.8 & 7.7 & 5.1 & 4.6 & 7.1 & 2.7 \\
\hline \multirow{4}{*}{ Glycerin } & $\mathrm{N}$ & 15 & 15 & 15 & 15 & 14 & 13 \\
\hline & Average (mg/cig.) & 2.27 & 1.31 & 4.76 & 2.47 & 1.29 & 4.85 \\
\hline & Standard deviation (mg/cig.) & 0.15 & 0.08 & 0.35 & 0.18 & 0.07 & 0.32 \\
\hline & $\mathrm{CV}(\%)$ & 6.8 & 6.1 & 7.3 & 7.4 & 5.2 & 6.7 \\
\hline \multirow{4}{*}{ Nicotine } & $\mathrm{N}$ & 15 & 15 & 15 & 15 & 14 & 13 \\
\hline & Average (mg/cig.) & 1.97 & 1.71 & 1.44 & 2.07 & 1.75 & 1.43 \\
\hline & Standard deviation (mg/cig.) & 0.13 & 0.09 & 0.13 & 0.11 & 0.10 & 0.09 \\
\hline & $\mathrm{CV}(\%)$ & 6.3 & 5.3 & 8.7 & 5.1 & 5.9 & 6.5 \\
\hline \multirow{4}{*}{ Water } & $\mathrm{N}$ & 15 & 15 & 15 & 15 & 14 & 13 \\
\hline & Average (mg/cig.) & 13.33 & 12.58 & 37.55 & 20.51 & 15.82 & 44.65 \\
\hline & Standard deviation (mg/cig.) & 2.01 & 2.00 & 2.81 & 2.04 & 2.58 & 2.47 \\
\hline & $\mathrm{CV}(\%)$ & 15.1 & 15.9 & 7.5 & 10.0 & 16.3 & 5.5 \\
\hline \multirow{4}{*}{ NFDPM } & $\mathrm{N}$ & 15 & 15 & 15 & 15 & 14 & 13 \\
\hline & Average (mg/cig.) & 30.33 & 25.38 & 17.76 & 23.27 & 20.97 & 10.24 \\
\hline & Standard deviation (mg/cig.) & 2.07 & 1.90 & 1.72 & 1.59 & 1.00 & 1.46 \\
\hline & $\mathrm{CV}(\%)$ & 6.8 & 7.5 & 9.7 & 6.8 & 4.8 & 14.2 \\
\hline \multirow{4}{*}{$\mathrm{CO}$} & $\mathrm{N}$ & 15 & 15 & 15 & 15 & 15 & 15 \\
\hline & Average (mg/cig.) & 30.35 & 23.48 & 0.50 & 31.59 & 23.19 & 0.49 \\
\hline & Standard deviation (mg/cig.) & 1.90 & 1.05 & 0.12 & 1.42 & 1.48 & 0.14 \\
\hline & $\mathrm{CV}(\%)$ & 6.3 & 4.5 & 23.2 & 4.5 & 6.4 & 27.8 \\
\hline
\end{tabular}


Table 4. Summary of increase and decrease of water and NFDPM deliveries for the in situ extraction methodology compared to the standard ISO methodology.

\begin{tabular}{|c|c|c|c|c|c|}
\hline \multirow{2}{*}{ Test item } & \multirow{2}{*}{ Analyte } & \multicolumn{2}{|c|}{ ISO smoking regimen } & \multicolumn{2}{|c|}{$\mathrm{HCl}$ smoking regimen } \\
\hline & & Relative & Absolute & Relative & Absolute \\
\hline \multirow{2}{*}{ PMI HTP } & Water & $+24 \%$ & $+4.45 \mathrm{mg} / \mathrm{cig}$ & $+19 \%$ & $+7.10 \mathrm{mg} / \mathrm{cig}$. \\
\hline & NFDPM & $-50 \%$ & - $4.68 \mathrm{mg} / \mathrm{cig}$ & $-42 \%$ & - $7.52 \mathrm{mg} / \mathrm{cig}$. \\
\hline \multirow{2}{*}{$3 \mathrm{R} 4 \mathrm{~F} \mathrm{CC}$} & Water & $+70 \%$ & +0.47 mg/cig. & $+54 \%$ & $+7.18 \mathrm{mg} /$ cig. \\
\hline & NFDPM & $-4 \%$ & - 0.37 mg/cig. & $-23 \%$ & - $7.06 \mathrm{mg} / \mathrm{cig}$. \\
\hline \multirow{2}{*}{ PMI CC } & Water & $+35 \%$ & $+0.23 \mathrm{mg} / \mathrm{cig}$ & $+26 \%$ & $+3.24 \mathrm{mg} / \mathrm{cig}$. \\
\hline & NFDPM & \multicolumn{2}{|c|}{ not significant (see Table 5) } & $-17 \%$ & $-4.41 \mathrm{mg} / \mathrm{cig}$. \\
\hline
\end{tabular}

of a PMI HTP or also when smoking CCs under HCI smoking regimen. The fact that the in situ extraction methodology shows a significantly more complete water recovery and results in lower NFDPM values is not by chance but because the in situ equipment and extraction methodology was designed to eliminate sources of water losses inherent in the standard ISO methodology. While the in situ extraction methodology shows a significantly more complete water recovery for all investigated cases the standard ISO methodology only shows agreeable results for low water content aerosols as the occurring losses are small in this case, i.e., CC smoke under ISO smoking regimen. For all investigated cases (CCs and a PMI HTP; ISO and HCI smoking regimen) the in situ extraction methodology resulted in equivalent levels or even in one case higher levels (3R4F smoked under HCI smoking regimen) of TPM, glycerin, nicotine, and CO compared to the standard ISO methodology. It can, therefore, be concluded that the in situ equipment and extraction methodology obtains a more complete water recovery and, thus, results in more accurate NFDPM values without impacting the results obtained for TPM, glycerin, nicotine, and CO yields.

To date we have not tested our in situ extraction methodology for the analysis of the aerosol generated by electronic cigarettes. However, as the aerosol for electronic cigarettes is very different compared to that of conventional lit-end cigarettes, i.e., contains higher levels of propylene glycol and glycerin, this methodology might also be more adequate for these type of products.

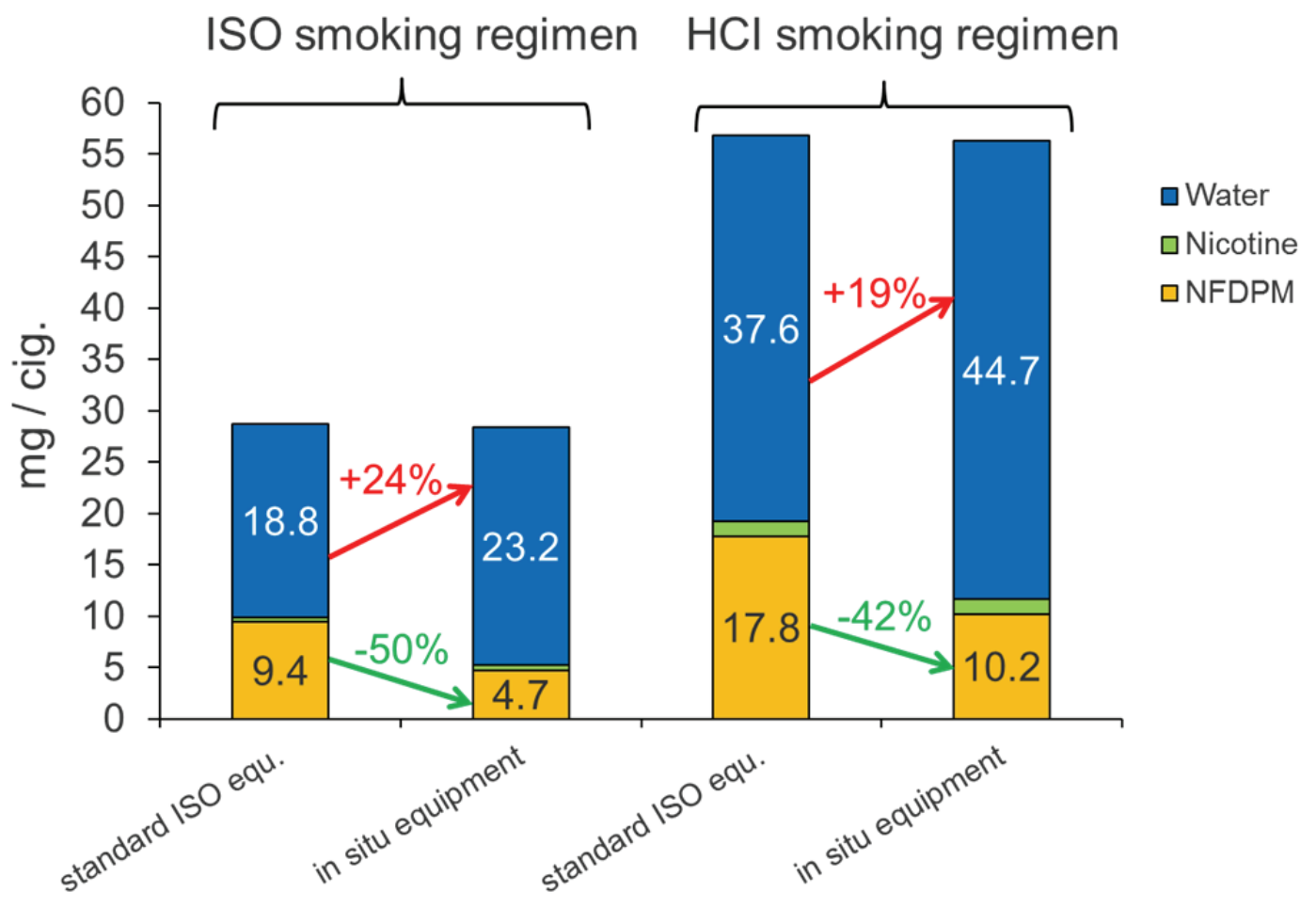

Figure 5. Graphical summary for PMI Heated Tobacco Product. 
Table 5. Statistical summary on the comparison between the in situ extraction methodology and the standard ISO methodology. The "=" indicates that no statistical difference between the in situ extraction methodology and the standard ISO methodology was found. The "+" and the "-" indicate that a higher or a lower yield, respectively, for the in situ extraction methodology compared to the standard ISO methodology was found.

\begin{tabular}{|c|c|c|c|c|}
\hline \multirow[b]{2}{*}{ Analyte } & \multicolumn{2}{|c|}{ ISO smoking regimen } & \multicolumn{2}{|c|}{$\mathrm{HCl}$ smoking regimen } \\
\hline & $\begin{array}{c}\text { Accuracy } \\
\text { (Difference in } \\
\text { mean values) }\end{array}$ & $\begin{array}{c}\text { Precision } \\
\text { (Difference in } \\
\text { variances) }\end{array}$ & $\begin{array}{c}\text { Accuracy } \\
\text { (Difference in } \\
\text { mean values) }\end{array}$ & $\begin{array}{l}\text { Precision } \\
\text { (Difference in } \\
\text { variances) }\end{array}$ \\
\hline \multicolumn{5}{|c|}{ PMI HTP } \\
\hline TPM & $=$ & $=$ & $=$ & $=$ \\
\hline Glycerin & $=$ & $=$ & $=$ & $=$ \\
\hline Nicotine & $=$ & $=$ & $=$ & $=$ \\
\hline Water & $+24 \%$ & $=$ & $+19 \%$ & $=$ \\
\hline NFDPM & $-50 \%$ & $=$ & $-42 \%$ & $=$ \\
\hline $\mathrm{CO}$ & $=$ & $=$ & $=$ & $=$ \\
\hline \multicolumn{5}{|c|}{ 3R4F CC } \\
\hline TPM & $=$ & $=$ & $=$ & $=$ \\
\hline Glycerin & $=$ & $=$ & $+9 \%$ & $=$ \\
\hline Nicotine & $=$ & $=$ & $+5 \%$ & $=$ \\
\hline Water & $+70 \%$ & $=$ & $+54 \%$ & $=$ \\
\hline NFDPM & $-4 \%$ & $=$ & $-23 \%$ & $=$ \\
\hline $\mathrm{CO}$ & $=$ & $=$ & $=$ & $=$ \\
\hline \multicolumn{5}{|c|}{ PMI CC } \\
\hline TPM & $=$ & $=$ & $=$ & $=$ \\
\hline Glycerin & $=$ & $=$ & $=$ & $=$ \\
\hline Nicotine & $=$ & $=$ & $=$ & $=$ \\
\hline Water & $+35 \%$ & $=$ & $+26 \%$ & $=$ \\
\hline NFDPM & $=$ & $=$ & $-17 \%$ & $=$ \\
\hline $\mathrm{CO}$ & $=$ & $=$ & $=$ & $=$ \\
\hline
\end{tabular}

\section{CONCLUSION}

The in situ equipment and extraction methodology shows a significantly more complete water recovery, resulting in more accurate NFDPM values while the partial water recovery obtained with the standard ISO methodology leads to inaccurate NFDPM values for high-water content aerosols. For CCs smoked under ISO smoking regimen, however, the difference obtained for NFDPM between both experimental methodologies is either not significant or not relevant according to the reporting requirements set forth in the ISO Standard 8243 (17) for printing of "tar", nicotine and $\mathrm{CO}$ yields per cigarette on cigarette packs. Consequently, the in situ extraction methodology applies to a wider range of smoking products and smoking regimens, whereas the standard ISO methodology only applies to a limited range of smoking products and smoking regimens. The in situ extraction methodology is an improved methodology to determine water and NFDPM without impacting the results of TPM, glycerin, nicotine, and CO yields for high-water content aerosols such as the aerosol generated by a PMI HTP or also when smoking CCs under more intense smoking regimens, such as the HCI smoking regimen. In cases where a comparison of yields between the PMI HTP and conventional cigarettes is required the in situ extraction methodology must be used for the aerosol of the PMI HTP to obtain accurate NFDPM/"tar" values. This would be for example the case if there were a need to print "tar" yields on packs or compare yields to ceilings. Failure to use the in situ extraction methodology will result in erroneous and overestimated NFDPM/"tar" values.

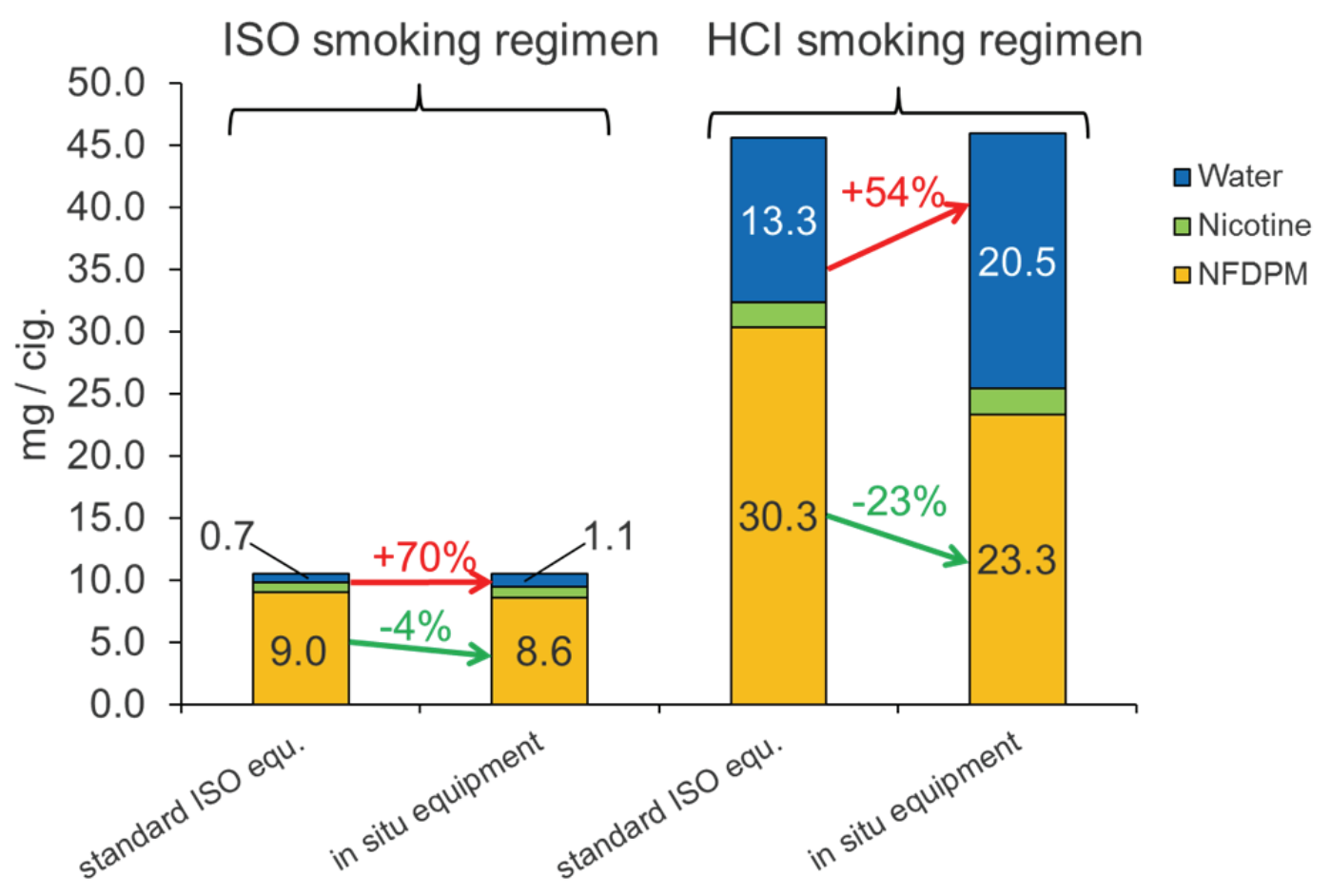

Figure 6. Graphical summary for 3R4F Reference cigarette. 


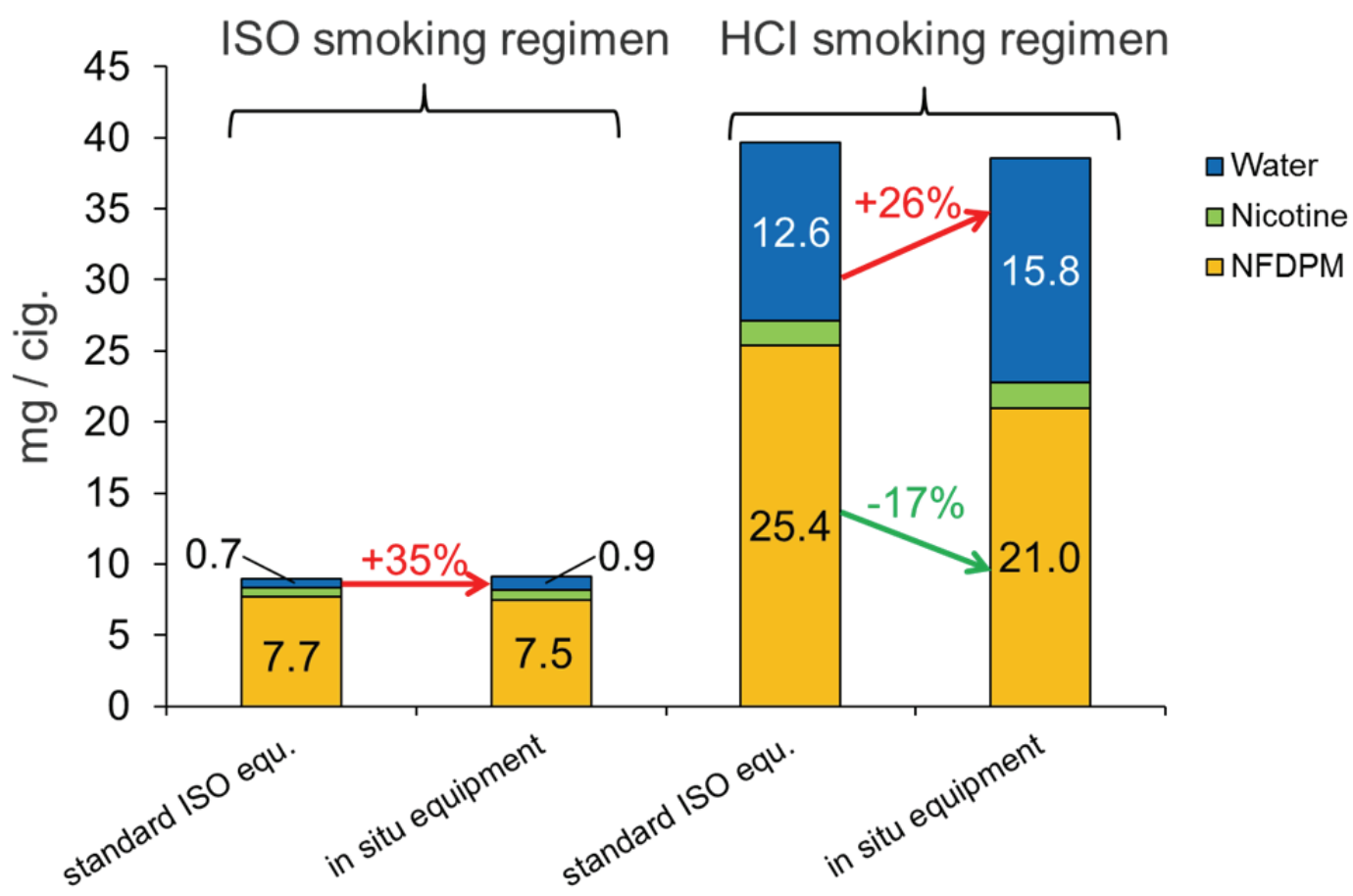

Figure 7. Graphical summary for PMI CC.

\section{REFERENCES}

1. International Organisation for Standardisation (ISO): International Standard ISO 3308:2012. Routine Analytical Cigarette-Smoking Machine -- Definitions and Standard Conditions; ISO, Geneva, Switzerland, 2012.

2. Health Canada: Tobacco Control Program "Determination of "Tar", Nicotine and Carbon Monoxide in Mainstream Tobacco Smoke", December 1999, available at http://legacy.library.ucsf.edu/documentStore/ $\mathrm{i} / \mathrm{w} / \mathrm{j} / \mathrm{iwj} 77 \mathrm{a} 00 /$ Siwj77a00.pdf (Accessed June 2014).

3. European Commission: Directive 2001/37/EC of the European Parliament and of the Council of June 5, 2001 on the Approximation of the Laws, Regulations and Administrative Provisions of the Member States Concerning the Manufacture, Presentation and Sale of Tobacco Products; Off. J. Eur. Commun. L194 (2001) 26-34.

4. Darrall, K.G.: Smoking Machine Parameters and Cigarette Smoke Yields; Sci. Total Environ. 74 (1988) 263-278.

5. Thomsen, H.V.: International Reference Method for the Smoking of Cigarettes; Rec. Adv. Tob. Sci. 18 (1992) 69-94, available at http://legacy.library.ucsf.edu/tid/ efu62a99 (Accessed June 2014).

6. Baker, R.R.: The Development and Significance of Standards for Smoking-Machine Methodology; Beitr. Tabakforsch. Int. 20 (2002) 23-41.

7. International Organisation for Standardisation (ISO): International Standard ISO 4387:2000. Cigarettes -Determination of Total and Nicotine-Free Dry Particulate Matter Using a Routine Analytical Smoking Machine; ISO, Geneva, Switzerland, 2000.
8. International Organisation for Standardisation (ISO): International Standard ISO 10315:2013. Cigarettes -Determination of Nicotine in Smoke Condensates -Gas-Chromatographic Method; ISO, Geneva, Switzerland, 2013.

9. International Organisation for Standardisation (ISO): International Standard ISO 10362-1:1999 - Cigarettes -Determination of Water in Smoke Condensates -- Part 1: Gas-Chromatographic Method; ISO, Geneva, Switzerland, 1999.

10. International Organisation for Standardisation (ISO): International Standard ISO 8454:2007. Cigarettes -Determination of Carbon Monoxide in the Vapour Phase of Cigarette Smoke -- NDIR method; ISO, Geneva, Switzerland, 2007.

11. Côté, F. and J. Verreault: Overestimation of Tar Yields at Canadian Intense Smoking Regime: Factors Affecting the Accuracy; Paper SSPT38, CORESTA Congress, Edinburgh, 2010, available at http://www.coresta.org/ Meetings/Past_Abstracts/Edinburgh2010-SmokeTech. pdf (Accessed June 2014).

12. Côté, F., J. Verreault, and F. K. St.Charles: Accuracy of Tar Yield Determination and Intense Smoking Regimes; $63^{\text {rd }}$ Tobacco Science Research Conference, September 27-30, 2009, Amelia Island, FL, USA.

13. Borgerding, M.F., R.D. Hicks, J.E. Bodnar, D.M. Riggs, E.J. Nanni Jr, G.W. Fulp Jr, W.C. Hamlin, and J.A. Giles: Cigarette Smoke Composition. Part 1. Limitations of FTC Method When Applied to Cigarettes That Heat Instead of Burn Tobacco; J. Assoc. Off. Anal. Chem. 73 (1990) 605-609.

14. Borgerding, M.F., L.A. Milhous Jr, R.D. Hicks, and J.A. Giles: Cigarette Smoke Composition. Part 2. 
Method for Determining Major Components in Smoke of Cigarettes That Heat Instead of Burn Tobacco; J. Assoc. Off. Anal. Chem. 73 (1990) 610-615.

15. CORESTA: CORESTA Recommended Method No. 23 Determination of Total and Nicotine-Free Dry Particulate Matter Using a Routine Analytical CigaretteSmoking Machine - Determination of Total Particulate Matter and Preparation for Water and Nicotine Measurements (August 1991); Available at http://www. coresta.org/Recommended_Methods/CRM_23.pdf (Accessed June 2014).

16. United States Pharmacopeia: General chapter $<1010>$ Comparison of Analytical Methods; USP 37-NF 32, 2014, ISBN 978-1-936424-22-1.

17. International Organisation for Standardisation (ISO): International Standard ISO 8243:2013. Cigarettes -. Sampling; ISO, Geneva, Switzerland, 2013.

Corresponding author:

David Ghosh

Philip Morris International

Research and Development

Quai Jeanrenaud 5

2000 Neuchâtel

Switzerland

E-mail: David.Ghosh@pmi.com 